\title{
Concept of Increase Enrolment: Its effect on teachers in Ghana
}

\author{
Hansen Akoto-Baako \\ University of Cape Coast, \\ Cape Coast, Ghana \\ Prem Jotham Heeralal \\ University of South Africa, \\ Pretoria, South Africa

\section{Bernard Kissi-Abrokwah} \\ C.K. Tedam University of Technology and Applied Sciences, \\ Navrongo, Ghana
}

DOI: https://doi.org/10.36941/mjss-2021-0o66

\begin{abstract}
This study investigated the effects of increase in enrolment on teachers in second cycle institutions in Ghana. The effects of increase enrolment on teacher's work load, classroom management, health, social life and classroom interaction. The study employed the pragmatic paradigm and mixed method approach. Concurrent triangulation comprising descriptive survey for the quantitative phase and a case study for the qualitative phase. Self-developed questionnaire and semi-structured interview schedule were used to collect data from respondents. A total of hundred and forty-seven (147) respondents were used for the study. It was made up of one hundred and forty (140) teachers used at the quantitative phase and seven (7) head teachers used in the qualitative phase. The study found out that increase enrolment increased the workload of teachers significantly, and exposed teachers to health challenges. The study also revealed that increase enrolment made it very difficult for teachers to manage their classrooms and interact with students during instructional periods. The study recommended that teaching assistants be assigned to all teachers, government should set up a special body which is made up of occupational counsellors, psychologists, physicians who will tasked to organize programs on monthly bases to educate teachers on how to manage work related stress they encounter. Finally, the government should build more schools and make it a priority to train more teachers.
\end{abstract}

Keywords: Increase Enrolment, Teachers, Ghana, Workload, Classroom Management, Social Lifestyle, SelfDevelopment, Classroom Interaction

\section{Introduction and Justification}

Arguably the high standard of education improves the developmental activities of every nation and wellbeing of individuals within a country (Akoto-Baako, 2018; Bullard, 2011). The high standard of 
education can be achieved through factors like class size where teaching and learning are being mediated, availability of teaching and learning resources, supervision, psychological classroom management environment and parental and governmental involvement (Akoto-Baako, 2018). In addition, Mwirigi and Muthaa (2015) believe that high and quality standard of education can be achieved based on the number of students teachers supervise in the classroom, teacher's qualification, teacher training, motivation and readiness of teachers to delivery of teaching in classroom. The researcher agrees with Mwirigi and Muthaa (2015), and suggests that for education to be considered as having quality standard, it has to do with teachers and the condition in which teaching and learning are being mediated in the classroom. Teachers' ability to deliver effective and efficient teaching comes when certain conditions prevail in their services to students. Such conditions include limited enrolment to ensure free movement in the classroom and with the good psychological classroom environment to ensure scaffolding during the course of teaching (AkotoBaako, 2018). When the number of students in classroom exceeds the stipulated number of forty (40) students by the Ministry of education in class, it is difficult to communicate learning goals. Also, poor ventilation, fatigue, health problems and other conditions affect the teacher and his/her work output. A report from the Ministry of Education (2018) shows that there has been an increase in enrolment of students from 7,101,763 to 13, 768,124 of students in Ghana. On the contrary, the report did not match the $100 \%$ increase to teacher's intake among schools in Ghana. Again, the Ministry of Education has also outlined "the challenges encountered as the cause of high enrolment due to the free senior high school education, among others as follows: (1) funding; (2) access; (3) staffing; (4) classroom space," (MoE, 2018) which have resulted in overcrowding in the senior high schools in Ghana. By way of controlling overcrowding in the classroom, the Ministry of Education has introduced the double track system of education. In spite of the implementation of free senior high school education, Ghana still faces challenges range from the poor psychological classroom environment, high student-teacher ratio and large class size due to the increase in enrolment (Akoto-Baako, 2018).

The purpose of education was to equip or empower students to acquire knowledge, develop skills and talents. However, Osei-Mensah (2012) asserted that the purpose of education may not be accomplished if mass enrolment of students was adopted without conforming to the class size which the teacher can handle to ensure the development to skill, talent and empowerment of knowledge. Osei-Mensah (2012) further stated that the increase in enrolment level in school without the corresponding increase in teacher's intake affect workload, classroom management, social lifestyle, self-development and classroom interaction.

In an attempt to provide quality second cycle education for all Ghanaians, the government implemented the "Free Senior High School Policy" in 2017 and the Double Track School System in 2018 with the intention of providing access to all students, especially those who qualify but are financially disadvantaged. The implementation of these policies has increased enrolment significantly. This has generated a lot of argument among stakeholders, Think Tanks and professionals in the educational sector and the entire nation. Among the issues discussed in the public domain were issues of large class sizes and the effects on the performances of teachers.

Akoto-Baako (2018) asserted that "the priority of a country, particularly developing countries, is to provide quality education to enhance the achievement of life goals by students because positive outcomes are largely dependent on the quality of education being provided. The quality level of education is focused on how well educators can handle classrooms and deliver their lessons efficiently without any hindrance. Many stakeholders are concerned with access to quality education provided in the country, but education at the senior high level has recently attracted attention due to the introduction of the Free Senior High School and the Double Track System Policy in 2017 and 2018 respectfully due to large class sizes in public senior high schools in Ghana.

The Ghana Education Service instituted teacher-to-student ratio of 1:40 to effectively improve the teaching and learning process in schools, however the increase of enrolment of students appears to be truncated. "The results of Jacob, Olawuyi and Jacob (2016) as cited in Akoto-Baako (2018) on the impact of class size on performance efficiency in senior high schools showed that" schools with an 
average class size of 35 and below had better results than schools with over 35 students per class in the review of secondary school certificates. A class that used to contain 35-40 students some time back now contains by more than $75-80$ students due to the implementation of these two policies which causes discomfort to teachers and students in the classroom. As a result of this phenomenon, the researcher wishes to investigate how it affects teachers. Most studies done on enrolment size and class size often focused only on the student's performance without taking into consideration the effect it has on the work and the wellbeing of teachers who play a pivotal role in the instructional process. This study examined the effects of increase enrolment on teachers.

\subsection{Research Question}

How does increase in enrolment affect teachers:

- Classroom management?

- Health?

- Social life?

- Classroom interaction?

\subsection{Research Hypotheses}

$\mathrm{H}_{1}$ : There is no significant relationship between workload of teachers and classroom management. $\mathrm{H} 2$ : There is no significant relationship between workload of teachers and their health problems. H3: There is no significant relationship between workload of teachers and their social life. $\mathrm{H}_{4}$ : There is no significant relationship between workload of teachers and classroom interaction.

\section{Theoretical Framework}

The theory of social constructivism by Lev Vygotsky guided this study. Social construction theory emphasizes the roles of social interaction and teaching. As Adam (2017) proposed, social construction theory establishes that development does not precede socialisation but rather, through social systems and social connections which contribute to the development of mental functions. Social contact is prominent in both teaching and learning. In this theory, the instructor who happens to teach in this case, transmits the search image of knowledge through interaction and it is through communication that students in particular learn from each other.

The theory of Vygotsky suggests that we learn first through person-to -person interactions and then individually through an internalization that leads to deeper understanding and this is focused on three (3) key themes that include: social interaction, the more experienced the other, and the proximal area of development (Adam, 2017). The key concept of Vygotsky's theory is that social interaction plays a fundamental role in the development of cognition. Thus, every function in the cultural process of child development, occur twice: the first process takes place at the individual level, while the second function is at the social level (Amineh \& Asl, 2015). Vygotsky suggested that development does not precede socialization but leads through social systems and social connections to the development of mental functions. The theory of Vygotsky suggests that we first learn through interactions between people and then individuals through a process of internalization that leads to deep understanding. Therefore, social interaction plays an important role in the education. Students learn from each other as well as from adults through social interaction.

The theory is generally based on three key themes which are the social interaction, the more experienced or knowledgeable other (i.e. teacher), and the zone of proximal development. Social interaction plays a crucial role in the cognitive development process. Unlike Jean Piaget's view of child development (in which development precedes learning automatically), Vygotsky's theory explains that social learning precedes development. In relation to a particular task, method or concept, the more knowledgeable others refer to someone who has a better understanding or a 
higher level of skill than the learner. Usually, the more knowledgeable other is assumed to be a teacher, mentor, or an older adult, but the more knowledgeable other might be friends, a younger person. The third theme of the theory is the proximal development area which is the difference between the ability of a student to perform a task under adult supervision and/or peer co-operation and the ability of the student to independently solve the problem. Learning takes place in this area, as Vygotsky (1978) rightly pointed out.

Moreover, in a mutual experience, Vygotsky stressed the relationships between people and the sociocultural sense in which they act and interact. According to Vygotsky (1978), humans use instruments that originate from tradition, such as speech and writing, to mediate their social interactions. Initially, children grow these instruments such that they can only act as social means to express their needs. The internalization of these strategies has led to a greater capacity to think. While Piaget connected development and information theoretically with internal changes, Vygotsky (1978) focused on external changes, with a focus on cultural contexts mediated by linguistic and other symbolic structures.

The means of transmitting culture and knowledge affect the way learners think, act, and the meaning they make (Vygotsky, 1978). The theory of social constructivism is an appropriate framework for delivering on the relationship between increase enrolment and teachers. The use of the zone proximal development can be applied in this study since the theory of social constructivism emphasises social interactions with the more experienced person, such as the teacher who promotes the learning process. A more competent individual, such as a teacher or mentor, needs to assist the student in order to help students achieve their academic potential; with this help, the student may be able to accomplish any given assignment.

Researchers have found that teachers are impaired by the increased number of students, as they now must cope with increased workloads (Ayeni \& Amankwae, 2018). Vygotsky (1978) is ideal for delivering on the rise in enrolment and its effects on students, according to any traditional principle of social constructivism. In this study, it is useful to use the proximal development zone because the philosophy of social constructivism is strongly concerned with social contact with the more experienced individual, such as the teacher, to facilitate the development of the classroom. Students in the zone of proximal development need to be regularly taught by educators. Teachers explain, model, and use directed teaching strategies in the classroom.

However, increase enrolment leads to large class size, teachers are unable to give the learners much attention, thus affect the teaching and learning procedure. Teachers are unable to submit or involve students in scaffolding, small groups, cooperative learning, group problem-solving, cross-age tutoring, assisted learning, and/or alternative evaluation in a situation of increase enrolment. It is not possible to have close interaction between teachers and pupils because teachers are constantly busy with too much of work and also due to the large class size, teachers will not be able to interact well with students as a class and also as individuals. Scaffolding is a type of adult support that allows a child or novice to solve a problem, perform a mission, or accomplish a goal beyond their unassisted efforts.

For the effective implementation of scaffolding as a learning method, the use of language and shared knowledge is fundamental. By learning and making inferences, students are able to decide when inferences should be made. Teachers need to provide students in the zone of proximal development with copies of particular sentences outlined in a short story. This theory is very suitable for this study since the theory emphasizes three key themes has (i.e. social interaction, zone of proximal development, and the more experienced others) that are central in this research. The teacher, who is the most experienced, uses social interaction to offer lessons and to gain input from students as well. Again, the teacher who is more experienced in the classroom uses the proximal development and scaffolding zone to help students perform tasks.

\section{Methodology}

The study was based on pragmatism philosophical assumption where concurrent triangulation mixed design was used to make in-depth assessment on how increase enrolment in Ghana affect teachers' 
day-to-day activities in their workplace (Creswell \& Creswell, 2018). The targeted population consist of all senior high schools (SHSs) in Ghana with a school population more than 3,00o and teachers' population less than 100. For the purpose of making in-depth assessment into the case, the researchers selected seven with high students' population and low teacher ratio.

The researchers purposively selected seven (7) SHSs and proportionate sampling technique was used with the help of Gay and Diehl (1992) procedure

for determining sample. They stated that when the accessible population was less than 200 units then selecting $\mathbf{2 0} \%$ may be appropriate for generalization. This procedure allows the researchers to draw externally valid conclusions about the entire population and also provides fair representation of respondents. The sample size selected was 147 which consist of one hundred and forty (140) teachers for quantitative phase and seven (7) head masters who were purposively selected from the seven (7) SHSs in Ghana.

Ethical clearance was sent to all metropolitan education educator directors. After access was granted, the researchers personally visited the SHSs to discuss the purpose of the study to participants. After several discussion the researchers positionality change from outsider to insider when other participants were asking the motive of conducting this research. The issue of confidentiality, anonymity and informed consent were discussed with them. The researchers used six (6) weeks for the data collection exercise.

Prior to the data collection, the instrument was pilot tested at the in Cape Coast metropolis. Piloting the instrument helped us to correct ambiguous questions and those that were not suitable for the study were reconstructed. The test-retest reliability procedure yielded a Cronbach Alpha level of 0.81 and 0.83 . However, the overall alpha level for the instrument was 0.82 . At the quantitative phase the data was analysed using Pearson Correlation coefficient and descriptive analysis was used for qualitative phase.

\subsection{Results-quantitative phase}

The results of the study were presented logically based on the research hypotheses of the study. As indicated earlier, inferential statistics and descriptive qualitative analysis were used to analyse the data.

$\mathrm{H}_{\mathrm{o}} \mathrm{l}$ : There is no statistically significant relationship between the workload of teachers and classroom management

The results in Table 1 showed significant with strong positive correlation between the workload of teachers and classroom management in the Ghanaian context. The result is reported as $\mathrm{r}=.861^{* *}$, $\mathrm{M}=22.43, \mathrm{SD}=.132$, sig. $=0.000^{* *} \mathrm{p}<0.05, \mathrm{n}=140$. The two variables (workload and classroom management) share a variance of $.861(86 \%)$. This implies that the variables predict themselves at $86 \%$. The results practically show that the workload of teachers at the SHSs positively predicts or is an influencing factor on teacher's ability to manage their classes. In other words, the higher the workload of a teacher, the difficulty the teacher faced in managing his/her classroom and vice visa.

Table 1: Correlation coefficients results between workload andclassroom management

\begin{tabular}{llcl}
\hline $\begin{array}{l}\text { Correlated } \\
\text { variables }\end{array}$ & \multicolumn{1}{c}{ M SD } & Workload & $\begin{array}{l}\text { Classroom } \\
\text { management }\end{array}$ \\
\hline Workload & $\begin{array}{l}\text { Pearson 22.43.132 } \\
\text { Correlation }\end{array}$ & 1 & $.861^{* *}$ \\
& $\begin{array}{l}\text { Sig. (2-tailed) } \\
\mathrm{N}\end{array}$ & 140 & $\begin{array}{l}0.00^{* *} \\
140\end{array}$ \\
Classroom & & & \\
Management & $\begin{array}{l}\text { Pearson 22.43.132 } \\
\text { Correlation }\end{array}$ & $861^{*}$ & 1 \\
& $\begin{array}{l}\text { Sig. (2-tailed) } \\
\mathrm{N}\end{array}$ & 140 & $0.000^{* *}$ \\
& & 140 \\
\hline
\end{tabular}

**. Correlation is significant at the 0.05 level (2-tailed) $(n=140)$ 
HA2: There is no statistically significant relationship between the workload of teachers and their health problems.

The results in Table 2 depict strong significant and positive relationship between the workload of teachers and their health problems in the Ghanaian context. The result is conveyed as $r=.893^{* *}$, $\mathrm{M}=16.73, \mathrm{SD}=.363$, sig. $=.002^{* *} \mathrm{p}<0.05, \mathrm{n}=140,2$-tailed. The two variables (workload and health problems) share a variance of .893 . In percentage wise, it is translated as $89 \%$. This implies that the variables predict themselves at $89 \%$ which essentially explains that the workload of teachers at the Senior High level is likely to create health related problems for the teachers. In other words, an increase in student's enrolment leading to teachers work overload could have an adverse effect on teacher's health status.

Table 2: Correlation coefficients results between workload and health problem

\begin{tabular}{|c|c|c|c|c|}
\hline $\begin{array}{l}\text { Correlated } \\
\text { variables }\end{array}$ & & SD & Workload & $\begin{array}{l}\text { Health } \\
\text { Problem }\end{array}$ \\
\hline \multirow[t]{3}{*}{ Workload } & $\begin{array}{l}\text { Pearson } 1 \\
\text { Correlation }\end{array}$ & 16.73 .363 & 1 & $.893^{* *}$ \\
\hline & Sig. (2-tailed & & & $0.02^{* k}$ \\
\hline & $\mathrm{N}$ & & 140 & 140 \\
\hline \multicolumn{5}{|l|}{ Health } \\
\hline \multirow[t]{3}{*}{ Problem } & $\begin{array}{l}\text { Pearson } 1 \\
\text { Correlation }\end{array}$ & 16.73 .363 & $893^{* *}$ & 1 \\
\hline & Sig. (2-tailed & & & $0.002^{* * *}$ \\
\hline & $\mathrm{N}$ & & 140 & 140 \\
\hline
\end{tabular}

Hoz: There is no statistically significant relationship between the workload of teachers and their social life

Table 3 offers the means, standard deviation and the correlation coefficients between the variables (workload and social lifestyle) for the hypothesis. As depicted in Table 3, the results gave an evidence of a significant and a strong positive relationship between workload of teachers and their social lifestyle in the Ghanaian context. The results were reported as $r=.793^{* *}, \mathrm{M}=19.14, \mathrm{SD}=.712$, sig. $=.001^{* *} \mathrm{p}<0.05, \mathrm{n}=140,2$-tailed. The two correlated variables (workload and social life) share a variance of. 793.Translating its percentage, it means that the variables predict themselves $79 \%$. The results basically mean that the workload of teachers at the Senior High level is likely to affect or influence the social life.

Table 3: Correlation coefficients results between workload and social life

\begin{tabular}{|c|c|c|c|}
\hline $\begin{array}{l}\text { Correlated } \\
\text { variables }\end{array}$ & SD & Workload & $\begin{array}{l}\text { Social } \\
\text { Lifestyle }\end{array}$ \\
\hline \multirow[t]{4}{*}{ Workload } & 19.14 .712 & 1 & $.793^{\circ 4}$ \\
\hline & \multicolumn{3}{|l|}{ Correlation } \\
\hline & \multicolumn{2}{|l|}{ Sig. (2-tailed) } & $0.001^{* *}$ \\
\hline & $\mathrm{N}$ & 140 & 140 \\
\hline \multirow{5}{*}{$\begin{array}{l}\text { Social } \\
\text { Life }\end{array}$} & & & \\
\hline & 19.14 .712 & $793^{\circ}$ & 1 \\
\hline & \multicolumn{3}{|l|}{ Correlation } \\
\hline & Sig. (2-tailed) & $0.001^{* * *}$ & \\
\hline & $\mathrm{N}$ & 140 & 140 \\
\hline
\end{tabular}

**. Correlation is significant at the 0.05 level (2-tailed) $(n=140)$ 
Ho4: There is no statistically significant relationship between the workload of teachers and classroom interaction

As shown in Table 4, the results show that there was a negative inverse significant strong positive relationship between workload of teachers and classroom interaction of teachers in Ghanaian senior high schools. The result is stated as $\mathrm{r}=.-925^{* * *}, \mathrm{M}=20.12, \mathrm{SD}=.522$, sig. $=.001^{* *} \mathrm{p}<0.05, \mathrm{n}=140$, 2-tailed. From the analysis, it is evident that the two correlated variables (workload and classroom interaction) share a common variance of -925 . Reading it in percentage wise, it means that the variables predict themselves at $93 \%$ showing how strong the relationship was. The results primarily show that workload of teachers at the Senior High level have a negative inverse relationship with the interaction. This means that the higher the workload of the teachers, the lower or less their interaction with their students.

Table 4: Correlations coefficients results between workload and classroom interaction

\begin{tabular}{|c|c|c|c|}
\hline $\begin{array}{l}\text { Correlated } \\
\text { variables }\end{array}$ & SD & Workload & $\begin{array}{l}\text { Classroom } \\
\text { interaction }\end{array}$ \\
\hline Workload & $\begin{array}{l}\text { Pearson } 20.12 .522 \\
\text { Correlation }\end{array}$ & 1 & $.925^{\circ}$ \\
\hline & $\begin{array}{l}\text { Sig. (2-tailed) } \\
\mathrm{N}\end{array}$ & 140 & $\begin{array}{l}0.001^{* *} \\
140\end{array}$ \\
\hline $\begin{array}{l}\text { Classroom } \\
\text { interaction }\end{array}$ & $\begin{array}{l}\text { Pearson } 20.12 .522 \\
\text { Correlation }\end{array}$ & $-925^{*}$ & 1 \\
\hline & $\begin{array}{l}\text { Sig. (2-tailed) } \\
\mathrm{N}\end{array}$ & 140 & $\begin{array}{l}0.001^{* *} \\
140\end{array}$ \\
\hline
\end{tabular}

\subsection{Result-qualitative phase}

The qualitative data was analysed using descriptive qualitative analysis. Seven (7) respondents who were headmasters of the selected SHSs were used for the study. The themes for the study were classroom management, teachers health, social life and classroom interaction.

\subsection{Effects of Increase Enrolment on Teacher's Classroom Management}

The description of respondents was presented below. TT3 revealed that,

"Work overload affects how the students are handled or cared for, education seeks for the individuality of each student but in the situation where students are overenrolled prevents teachers from reaching to each student well as they would do for a smaller class, quality in teaching becomes low as less average students might not get to be handled properly because the class size is large"

In addition, TT5 confirmed:"Increase enrolment makes it impossible to control the learning, maintain order and organise student learning. Since the classroom is a space supposed to take a certain number of students for effective teaching and learning, creating an environment that support and facilitate effective teaching and learning and social-emotional learning becomes impossible. No way to get an organized class for lessons and when we tried to get the class organized, it turns to take all the time allotted for the lesson".

However, when asked how increase in enrolment affects teachers, $\mathrm{TT}_{1}$ and $\mathrm{TT}_{7}$ shared similar view, due to the large number of students in classrooms, teachers are not able to control the students and it was very hard for teachers to keep an eye on all the students in the class. They further stated that: 
"Teachers spend instructional time in handling recalcitrant students instead if teaching. They feel very tired every day during and after school hours because they invest all their energy shouting, disciplining and controlling these students. Because of the large class which is as a result of increase enrolment teachers find it difficult to make sure that individual students adhere to classroom rules and regulations" (TT1).

"There are now more students in the classroom, it means there will be more noise and more distractions than before. This has made it all the more difficult for me to keep my classes in line while delivering the lesson alongside. Also, Increased enrolment affects teacher's classroom management in that, class control during lesson delivery and other important tasks becomes difficult. Management of a noisy classroom environment also becomes an issue due to the overcrowding of students. In this regard, appropriate punishments cannot be meted out to students with constant misbehaviour. Relating to the difficulties experienced by teachers the general teaching and learning process becomes ineffective" (TT7).

TT2 answered that, "Enrolment has increased with government's idea of making senior high school free and compulsory. In the process of teaching teachers are unable to reach out to every student individually due to the increased number of students in the classroom and because of this the seating arrangement has also change with no space to pass through to help me monitor students while teaching and this give them the chance to misbehave in the classroom".

$\mathrm{TT}_{4}$ also revealed that, "Increase enrolment affects teacher's classroom management because they find it difficult to control students during and after lessons. It also makes it difficult to ensure that student comply with all classroom rules and regulations. Managing large group of students with different temperament in a classroom is not an easy task for a teacher to fulfil. Increase enrolment makes it difficult for teachers to have awareness of the individual students' skills and performance. Class control also becomes another problem because there are more students than the normal in my class".

Lastly, TT6 commented that, "Large class sizes are always identified with noise making, bullying, stealing, quarrying and, poor performance. These make it a lot more challenging to manage such class successfully. There is always some kind of problem in the class and trying to find a solution to it takes the periods for the lesson. Maintaining order and good class arrangement is something impossible and also no space to be able to move freely to get to the students and to get them organized".

\subsection{Effects of Increased Enrolment on Teacher's Health}

All the respondents commented on this theme. Most of the head teachers were concerned about the health of their teachers. The respondent's narration was presented below. TT2 explained that "the main health issue teachers face is stress which normally comes with persistent headaches. However,

TT1 asserted:"Teachers feel so stressed during and after school period because students in their class are too many for them to handle. They experience headache, fatigue every day because of the extra energy used in shouting at disruptive students. Some complain they get so tired and sick every day when they get home".

Also, TT2 added that, "Due to the large class sizes, delivering the lessons also becomes more demanding as teachers have to shout more for the students to hear and to repeat more often for all of them to pick up. After the lessons, they have to mark large numbers of exercises. All these put so much physical and psychological stress on them".

However, $\mathrm{TT}_{3}$ said that,"The potential health problems pertaining to the teaching of large classes ranges from many to infinity. Aside the fatigues, which is expected in dealing with large class sizes, another health issue teachers experience is headaches".

In the same vein, TT2 confirms that:"The stressful nature of handling a large class can even lead to psychological imbalances including mood swings. In addition to that, due to the more time needed in 
dealing with these kinds of class situations, bad eating habits can become the new normal to the teacher thereby leading to illnesses such as stomach ulcers, constant constipation, nausea and insomnia. These health issues seem to be overlooked because people with these illnesses seem well, but one can be sure of the long-term challenges associated to this".

$T_{4}$ stressed that,"Handling a large number of students, the noise level is inevitably high which at the end causes stress. Voice disorder, as teachers would have to talk loudly for the whole noisy class to hear therefore, their voices are always affected. Another health problem they always face is headache, which continues for two to three days. There are some other minor health issues teachers face as a result of the large class size which are, neck pain, shoulder pain and difficulty in sleeping".

TT5 complained that,"Teachers have to shout for those at the back to hear me clearly, in doing so this affects their throat because they shout on daily basis, sometimes they get home so tired that they are not able to cook and so rely on sweets and junky foods they get on their way home".

TT6 complained that: "Due to the large number of students in the class, teachers always have to be talking on top of their voice for the hearing of all students and this result in headache at the end of the instructional period. Also, the workload like supervising students during exercises and marking exercises causes fatigue. Teachers also complain of difficulty in sleeping, back pain, stress and eye pain".

Finally, $\mathrm{TT}_{7}$ confirms that, "Due to the large number of students in the classrooms teachers always have to be shouting on top of their voice for the hearing of all students and this result in headache at the end of instructional period. Also, the workload like supervising students during exercises and marking exercises causes fatigue. There are many health problems but the frequent and common ones they experience are headache and fatigue".

\subsection{Effects of Increase Enrolment on Teacher's Social Life}

All the respondents' response to this theme. TT1 emotionally responded that,

"As a result of the number of classes teachers have to teach, they spend most of their time after school preparing lessons for the next day or marking exercises and scoring essays so that they will be ready for discussions in the next lesson. This increase in work means they have less time for going out and engaging in social activities. Also, teachers do not have social life at all. According to them their friends even call them Anti-social. All these is because increase enrolment has caused their class size to double and the workload has also doubled and so they are always working and do not have to time to participate in any social events".

TT2 was of the view that, "social life is a very integral aspect of the teacher, as well as all humans. But as the days go by, due to large class, which is as a result of increase enrolment, teachers are gradually losing this aspect of life. Increasing student enrolment means increasing the number of tasks for the teacher".

Interviewer: so, please what social activities are you affected with in life? TT2 further asserted:

"The teacher has to use his time for social activities such as attending naming ceremonies, weddings, funerals, and a host of events for the marking of scripts of students, grading and recordings of reports of students. Also, since the teacher needs extra efforts in preparing for large class as compared to the average class, the teacher's time is reduced to purely academic work. This is because the teacher of a large class needs innovative skills and techniques to have an effective learning and learning experience".

TT3 answered:"Now a day, teachers have no social life. They are buried in the work that some cannot remember the last time they went out with family and friend or even travel home on a festive season because of the increase enrolment. There is always work to be done and must meet the deadline. Phone 
calls and even social networking are something rare for them. Family and friends are always complaining about the anti-social lifestyle the work has turned them into".

TT4 was of the view that,It has negatively affected the social life of teachers because they do not get enough time to go out with family and friends because the little time they get must be using it for resting or visiting the doctor. Sometimes, teachers have to work overnight to forgo a family outing. In the house when they are supposed to have time with their families, they still work and so they turn to make the family conversation uninteresting always.

TT5 said that,Honestly, because of the work overload from school all the time teachers are not able attend any social gathering. They also do not have the time to participate in activities organized in their communities. Teachers always come home with lots of surplus work from school and does not have time to even interact with members of my community. At times, teachers have to take students' assignments home to be assessed. This affects them in a way that they do not have time to associate with my family and also engage in certain gatherings during the weekends and festive occasions. Increase enrolment affects their social life because as a result of the stressful activities for the day they get too tired to do other things

TT6 complained that,Because of the increase enrolment, most teachers send some of the unfinished marking assignments to the house to be completed for feedback to the students and work upon the weak areas where they did not get much understanding and by so doing they are unable to interact properly with their family. Teachers sometimes forget to even help the kids with their home assignment. They hardly go for the normal evening church service because by that time they would be tired already and so go to bed. Visiting friends have been a thing of the past because either they are preparing something to teach or feeling report cards.

$T_{7} 7$ responded,There will be limited time for my social activities. I don't get the time to attend some social gathering such church, party and others because of tiredness after school and over time works. Increase enrolment affects my social life because as a result of the stressful activities for the day I get too tired to do other things organised in my community. Even on Sunday, they do not have the time to accompany my family to church because they either preparing lesson notes, marking classroom exercises or filling assessment forms. Honestly speaking, most teachers do not have any social life anymore.

\subsection{Effects of Increased Enrolment on Teacher's Classroom Interaction}

From the theme the respondents were of the view that they the increase in enrolment was affecting their classroom interaction with the students.

TTI said that, "It is very difficult to know all the students in their classroom. The number was too much that teachers are unable to interact with students. Even during lessons, teachers are unable to attend to their individual needs because they are operating in large class size. Under normal circumstances, they should be able to interact with students and know their problems and also help them out, but the class size is too large to perform that act".

Also, TT2 added that,"It is difficult for teachers to know all students personally in large class size. Because of the large sizes of the classes, teachers struggle to keep up with the names of the students and their individual challenges. So, they always have to choose between focusing on achieving the day's objectives and neglecting individual issues or focusing on the individual and not achieving objectives for the lesson".

In the same vein, $T_{3}$ and TT6 were of the view that "increase enrolment affects teacher's ability to work with all students in the class".

They further asserted:

"The effectiveness of a learning process is determined by ability to interact with all your students. The 
teacher needs to know the strengths and skills of your students as well as their flaws and weaknesses. However, due to the overcrowding as a result of the increased enrolment, they are unable to attend to the need of all students. Again, differentiated tasks and assignments to students are not effective even if possible. Grouping of student for assignments and assessment is difficult" (TT3).

"Teachers are not able to get to know each student well and help them with their problems as interactions are easier in a small class size. Due to the large number of students, interacting with students during the course of lessons to ensure full participation of students has become very difficult. Also addressing students' problems after lessons has become burdensome because of their large number" (TT6).

In addition, TT4 confirms that, "Interaction with students is very important in achieving great academic success but with larger class size, the contrary is obvious. Teacher time with the students is always limited and thus, good interaction becomes something they can only hope for. The maximum time teachers sometimes spend with the students is two minutes and because of the stress they go through, they easily irritated which also a hindrance to their ability to interact with the students".

TT5 responded that,"Normal class size makes it possible to easily interact with students which also brings improvement in academic performance. Getting to know each student would have been the best idea for smooth interaction, but with large class size, teachers hardly get to interact with the students and have not even spoken to some of them one on one. They are only able to interact with those at the front but just briefly. And without interacting with the students, identifying each student's needs and addressing them becomes a very difficult situation. Therefore, their various needs are not met".

Lastly, TT7 answered by saying, "As a result of the increase enrolment teachers are unable to know students and also interact with them individually in the course of instruction. This is because each student has his or her own problem and whiles interacting with them one by one through guidance or counselling time too will not be left for us therefore the successful nature of teacher and student relationship is always not meet. At times, there will be the need to visit students in their home to check up on them how they also learn after but due to the overload of work at schoolteachers are tired already of which such a nice idea cannot be executed".

\section{Discussion}

The discussion focuses on how increase enrolment on teachers' workload, classroom management, health, social lifestyle and classroom interaction.

\subsection{Effects of Increase Enrolment on Teachers' Workload}

The study delivers significantly a better result indicating that teachers always get tired and exhausted both at home and at school due to the excessive workload on them, most of the teachers were found to be always under pressure both at work and at home due to work overload from school, most the of teachers mostly become emotionally exhausted every day after school because of work overload. Wangeri and Okello (2014) found that if teachers suffer from work stress, their students are negatively affected because the students may not have a pleasant environment with their teachers and may not pass crucial tests, thereby affecting their future prospects.

In the same vein, the qualitative data shared similar results with the quantitative data. However, TT1 and TT6 shared that because of workload, which was as a result of increase enrolment, the teachers are always under pressure because of workload. These ranges from marking, recording, filling of report cards and assessment sheets. Again, other respondents lamented that their class work is so much that they always have to carry work from school to the house to continue $\mathrm{TT}_{3}, \mathrm{TT}_{5}$ \& $\mathrm{TT}_{7}$ ). The researchers assert that teachers get tired and exhausted every day during school hours, because of the work overload on them, they are not able to meet their instructional objectives for each instructional session. As a result, most teachers are not able to complete the syllabus for the 
term and even the academic year. In support, Nkweke and Dollah (2011), revealed that teaching staff carry home their work after school period, to prepare them for the next day's activities. The teacher prepares his/her lesson note at home, mark and record examination scripts at home.

The researcher believes that teachers are expected to provide essential services such as notes planning, effective lesson delivery, proper monitoring and evaluation of student performance, regular feedback on student performance, sufficient record keeping and sufficient student discipline to achieve and improve the required learning quality. The results from the current study are not in isolation, however, they lend a support for Wangeri and Okello's (2014) whose study revealed that work-stressed teachers are more likely to suffer job dissatisfaction, reduced emotional and physical wellbeing than their non-stressed colleagues. These assertions are in line with my findings that most of the teachers are always pressured both at work and home as a result of work overload from school.

Drawing inferences from the qualitative data, TT1 pointed out that teachers are not able to complete their syllabus every year because their workload was too much and this is because the number of students in their classes are too many. They also get so tired by the time most of them get home from school because the workload is too much on them. Similarly, a data from the 2013 GallupHealth-ways Well-Being Index shows that (46\%) of teachers in K-12 settings experience high daily stress levels during the school year (Lever, Mathis \& Mayworm, 2017).

\subsection{Effects of Increase Enrolment on Teacher's Classroom Management}

To a large extent, it was believed that students would even like to know how they are managed and so teachers need to understand the management skills to be used to control their students. In the quantitative data, it was evident that teachers feel very tired and exhausted every day after school as a result of extra energy spent on making sure students comply with classroom rules, teachers were unable to handle, supervise and attend to students as individuals as a result of large class size. In the same vein, the qualitative data showed that work overload affects how the teachers are handled or cared for students. In the quest to manage classrooms, most teachers feel very tired and exhausted every day after school as a result of extra energy spent on making sure student comply with classroom rules. This agrees with the claim that overcrowding has a number of detrimental behavioural effects on teachers. For example, students cannot pay attention or participate at the appropriate intensity level because classmates are noisy and resistant (Mustafa et al., 2014; Qasim \& Arif, 2014), resulting in a negative impact on academic achievement (Bayat, Louw \& Rena, 2014). Consequently, it is certainly much of the fact that large classes must involve assertiveness, management, and active teachers who are capable of controlling most class actions.

Again, the quantitative data show that inability to identify disruptive students due to large class size and teachers were unable to track and supervise students behaviour and movement in the classroom as a result of overcrowded classrooms. However, $\mathrm{TT}_{4}$ also confirmed that managing large group of students with different temperament in a classroom is not an easy task for a teacher to fulfil. In the same vein, other respondents commented that increase enrolment makes it difficult for teachers to have awareness of the individual students' skills and performance. For example, a study by Mwirigi and Muthaa (2015) indicated that teachers and head teachers agreed with the feelings that lack of classroom management due to increase in students' enrolment affected students learning performance as there were noise making and poor class discipline. Also, teachers were unable to label all the exercises given to the students as a result of large classrooms.

Dealing with the hypothesis of the study, it was clear that there is a significant strong positive relationship between workload of teachers and classroom management in the Ghanaian context. The results were reported as $\mathrm{r}=.793^{* *}, \mathrm{M}=19.14, \mathrm{SD}=.712$, sig. $=.001^{* *} \mathrm{p}<0.05, \mathrm{n}=140,2$-tailed. The two correlated variables (workload and classroom management) share a variance of. 793. The study support the opinions of the head teachers that due to the large number of students in classrooms, teachers were not able to control the students. 


\subsection{Effects of Increase Enrolment on Teacher's Health}

It was found that teachers experience stress and burnout every day during and after school hours as a result of handling large classes. In the hypothesis data, it was juxtaposed that there was a significant strong positive relationship between workload of teachers and their health problems in the Ghanaian context. The result is conveyed as $r=.893^{* *}, \mathrm{M}=16.73, \mathrm{SD}=.363$, sig. $=.002^{* *} \mathrm{p}<0.05, \mathrm{n}=140$, 2-tailed. This was validated by the headmasters who pointed out that teachers felt stressed during and after school period because students in their class were too many for them to handle. They experienced headache, fatigue every day because of the extra energy used in shouting at disruptive students. Some complained they got so tired and sick every day when they get home.

Also, teacher burnout is a form of chronic reaction that has a negative impact on the teachers as Wangeri and Okello (2014) found that burnout is prevalent in occupations such as teaching and human services. Previous studies of some research indicated that due to the complexity of cultivating an effective teaching method by the teacher, it may be beyond the developmental scope of the newly graduated teacher. Findings from the study (both qualitative and quantitative evidence), revealed that teachers experienced a lot of stress throughout their careers of teaching in large classes. Since increased enrolment results in a larger class size, poor working conditions and unfavourable physical environment have been found leading to stress among teachers. Correspondingly, Herman, Reinke, Stormont, Puri and Agarwal (2010) studied 129 teachers in grades K-4 of 1,817 pupils with an evaluation of latent profiles to group participants into four groups identified by stress, coping and burnout.

\subsection{Effects of Increase Enrolment on Teacher's Social Lifestyle}

Increase enrolment which has affected teachers' work conditions has made it almost impossible for teachers to balance their social lives with their work. Teachers do not have time to interact with other important people, including spouses and children in their lives. As a consequence, teachers are therefore more likely to experience conflict between the roles of work and family. Corroborating with the hypothesis data, it was asserted that there is a significant strong positive relationship between workload of teachers and their social lifestyle in the Ghanaian context. The results are reported as $r=$ $.793^{* *}, \mathrm{M}=19.14, \mathrm{SD}=.712$, sig. $=.001^{* *} \mathrm{p}<0.05, \mathrm{n}=140,2$-tailed. The two associated variables (workload and social lifestyle) share a variance of. 793. Meaning that the more the work load the less social life teachers have. From the results, it can be asserted that socializing is vital when it comes to maintaining good mental health. Indeed, lack of social contact can result in stress, as well as a raft of other problems such as poor self-esteem and depression. In a similar context, Palmer, Rose, Sanders and Randle (2012) pointed out that, teachers with dependent children at home may spend a large amount of time managing children (some of whom may have emotional or behavioural problems) in their workplace, in addition to the demands of raising their own children when they are at home.

In the hypothesis, it was found that there was a negative inverse significant strong positive relationship between workload of teachers and classroom interaction of teachers in Ghanaian senior high schools. The result is stated as $\mathrm{r}=.-925^{* * *}, \mathrm{M}=20.12, \mathrm{SD}=.522$, sig. $=.001^{* *} \mathrm{p}<0.05, \mathrm{n}=140,2-$ tailed. From the discussions, Chingos (2013) was right when he rightly pointed out that decrease enrolment where class size was small, there are more objections for teacher-student interaction with individuals receiving instruction from the teacher in the classroom. Therefore, parents prefer lesser classes. Parents believe that in classes that do not have a large number of learners, their children will perform much better.

\subsection{Effects of Increase Enrolment on Teacher's Classroom Interaction}

Due to large class sizes, teachers struggle to keep up with the names of the students and their individual challenges. This implies that they always have to choose between focusing on achieving 
the day's objectives and neglecting individual issues, or focusing on the individual and not achieving objectives for the lesson. In the hypothesis, it was found that there was a negative inverse significant strong positive relationship between workload of teachers and classroom interaction of teachers in Ghanaian senior high schools. The result is stated as $\mathrm{r}=.-925^{* * *}, \mathrm{M}=20.12, \mathrm{SD}=.522$, sig. $=.001^{* *} \mathrm{p}<$ $0.05, \mathrm{n}=140$, 2-tailed. From the discussions, Chingos (2013) was right when he rightly pointed out that decrease enrolment where class size was small, there are more objections for teacher-student interaction with individuals receiving instruction from the teacher in the classroom.

The results suggested that the workload of teachers as a result of increased enrolment at the Senior High level have a negative inverse relationship with the interaction. This means the higher the workload of the teachers, the lower or less their interaction with their students. The results from the study further indicated that classroom interaction is greatly affected by increase enrolment on teachers. For example, it was revealed that due to large class size, teachers were unable to use interaction - based instruction to deliver the lesson. These findings are similar to the result of a survey conducted in New York class size reduction programmes; the teachers also stated that teachers were unable to use interaction-based instruction to deliver because of large class size (Finn, 2003).

\section{Conclusion}

The following conclusions were drawn from the study:

- The study concluded that increase in enrolment has no positive effect on the teachers but the negative which result into health problem and inability for self-development.

- The study established that increase in enrolment had a high effect on teacher's workload, classroom management and classroom interaction where health, and social lifestyle were the least effect of the increase in enrolment for teachers.

\section{Recommendations}

- The government should build more schools to add up to the already existing ones. This would help reduce overcrowding in the classroom, thereby reducing workload on teachers.

- Government should also recruit more teachers to meet up with the growing population and also add up to the inadequate number of teachers we have who are experiencing the negative effects of work overload.

- Government through the Ministry of Education (MoE) and Ghana Education Services (GES) should invest in technology that can be put to greater use such as Information and Communications Technology (ICT) teaching in the classroom to free teachers from workload and empower them to do what they do best.

- Provision of adequate infrastructures: Government should provide adequate school infrastructure especially classrooms to accommodate the growing numbers of students in senior high schools.

- The government should institute policies that allow for compulsory leaves for teachers during the academic calendar. This would enable teachers take some time off all academic activities. This would go a long way to help teachers improve their social lives which would improve their health.

\section{Theoretical Implications}

The social constructivism by Lev Vygotsky was significant to this paper because it provides learners with a search image to enhance learning and to improve the other human development domain. It is through social contact that teachers understand and listen to the needs of individual students during 
and after periods of instruction. It is also through social interaction that teachers scaffold students who are in the zone of proximal development.

Social interaction has become extremely difficult for teachers in the classroom because of large classes which are as a result of increase in school enrolment. This affects the teachers because it makes it difficult for them to achieve their instructional objectives and the educational goals in general. Smaller classes encourage social interaction and enhance teaching and learning and help the teacher to achieve his objective. Smaller class size allows the teachers to undertake professional development programs that enhance them with the requisite skills for effective social interaction with students.

The teacher who is more knowledgeable person moderates and regulate all classroom activities. The success or otherwise of the teacher in his duties depends on the classroom conditions in which teachers find themselves. Favorable classroom conditions optimize teacher output and vice versa. Smaller class sizes enable the more knowledgeable other who is the teacher to engage in well planned and organized social interaction, provide scaffolding for students in the zone of proximal development, attend to collective and individual needs in the classroom.

Large classes which are as a result of increase enrolment has made it difficult for teachers to scaffold and interact with students and this affects teacher output. The proliferation of large classes in the second cycle institutions in Ghana has as a result of increase in school enrolment made the work of teachers very difficult. Large classes affect the health, classroom management, classroom interaction, social life and the professional development of teachers who double as the more knowledgeable other and as a result of this, teachers cannot function properly in the classroom as compared to smaller classes.

The zone of proximal development as the distance between the actual developmental level as determined by independent problem solving and the level of potential development as determined through problem solving under adult guidance or in collaboration with more capable peers. A teacher or the more experienced others and a learner work together on an assignment in the zone of proximal development that the learner could not accomplish individually due to the degree of difficulty.

It also describes the principle of collaborative action, where those who know more or are more competent share the experience and ability to perform a role with those who know less. When working in the proximal development region, a good deal of directed involvement is needed and learners bring their own understandings to social interactions and create definitions by combining those understandings with their experiences in the context.

Teachers can effectively interact and scaffold students at the zone of proximal development when the class is not crowded. Increase enrolment has resulted in large classes and overcrowded classes which have made it very difficult for teachers to provide scaffolding for student in the zone of proximal development. Smaller classes allow teachers to offer assistance to the entire class and as individual students.

It is imperative to note that the social constructivism contributes greatly to teachers in understanding the need for knowledge practicing zone of proximal development, scaffolding and social interaction with the students.

\section{References}

Adam, I. (2017). Vygotsky's Social Constructivists Theory of Learning. Unpublished Research Paper.

Akoto-Baako, H. (2018). Perceived influence of large class size and psychological classroom environment on students academic performance (Doctoral dissertation, University of Cape Coast).

Amineh, R. J., \& Asl, H. D. (2015). Review of constructivism and social constructivism. Journal of Social Sciences, Literature and Languages, 1(1), 9-16.

Ayeni, A. J., \& Amankwae, A. P. (2018). Teachers' Instructional Workload Management and Students' Academic Performance in Public and Private Secondary Schools in Akoko North-East Local Government, Ondo State, Nigeria. American International Journal of education and Linguistics Research, 1(1), 9-22. 
Bayat A, Louw, W. \& Rena, R. (2014). Investigating the confluence of factors impacting on underperformance at selected secondary schools in the Western Cape, South Africa. International Journal of Educational Sciences, $7(1): 41-55$.

Bullard, H. C. (2011). The effects of school enrolment size on student achievement (Doctoral dissertation, Georgetown University).

Chingos, M. M. (2013). Class size and student outcomes: Research and policy implications. Journal of Policy Analysis and Management, 32(2), 411-438.

Creswell, J. W., \& Creswell, J. D. (2018). Research design: qualitative, quantitative, and mixed methods approaches. Sage publications.

Gay, L. R., \& Diehl, P. L. (1992). Research methods for business and management. New York: Macmillan.

Herman, K. C., Reinke, W. M., Stormont, M., Puri, R., \& Agarwal, G. (2010). Using prevention science to promote children's mental health: The founding of the Missouri Prevention Center. The Counselling Psychologist, 38(5), 652-69o.

Lever, N., Mathis, E., \& Mayworm, A. (2017). School Mental Health Is Not Just for Students: Why Teacher and School Staff Wellness Matters. Report on emotional \& behavioural disorders in youth, 17(1), 6-12.

Ministry of Education School Profile, (2018). Primary education manuscript. Accra: Ghana Publishing Co Ltd.

Ministry of Education. (2018). Free Senior High School Implementation guidelines. Accra, Ministry of Education.

Mustafa, H. M., Mahmoud, S., Assaf, I. H., Al-Hamadi, A., \& Abdulhamid, Z. M. (2014). Comparative analogy of overcrowded effects in classrooms versus solving 'cocktail party problem' (neural networks approach). Ratio, 5(10), 20-39.

Mwirigi, S. F., \& Muthaa, G. M. (2015). Impact of Enrolment on the Quality of Learning in Primary Schools in Imenti Central District, Kenya. Journal of Education and Practice, 6(27), 156-16o.

Nkweke, G. O., \& Dollah, S. A. (2011). Teaching Staff Strength (TSS) and Workload in Public Senior Secondary Schools In Ogba/Egbema/Ndoni Local Government Area of Rivers State, Nigeria. Mediterranean Center of Social and Educational Research, 2, 25.

Osei-Mensah, F. (2012). Factors that influence the performance in general knowledge in art of senior high school students in Abura Asebu Kwamankese District in the Central Region (Doctoral dissertation).

Palmer, M., Rose, D., Sanders, M., \& Randle, F. (2012). Conflict between work and family among New Zealand teachers with dependent children. Teaching and Teacher Education, 28(7), 1049-1058.

Qasim, S., \& Arif, M. S. (2014). The inadequacy of academic environment contributes to inadequate teaching and learning phenomena. Educational Research and Reviews, 9(5), 141145 .

Wang'eri, D., \& Okello, L. W. (2014). Role overload, teacher-pupil-ratio, school type, years of teaching experience, gender and burn out as factors related to work stress among primary school teachers in Kasarani

Division, Nairobi County, Kenya. Mediterranean Center of Social and Educational Research, 4, 21-34.

Wangeri, T., \& Okello, L. W. (2014). Role overload, teacher-pupil-ratio, school type, years of teaching experience, gender and burn out as factors related to work stress among primary school teachers in Kasarani

Division, Nairobi County, Kenya. Global Journal of Human Social Science-GJHSS-G, 14(1). 